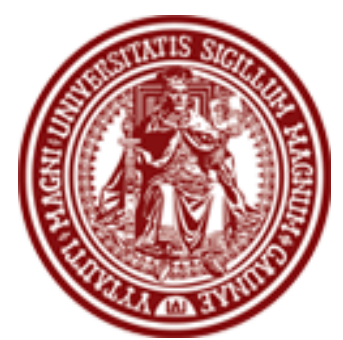

DE DE GRUYTER OPEN G
BALTIC JOURNAL OF LAW \& POLITICS

A Journal of Vytautas Magnus University

VOLUME 8, NUMBER 2 (2015)

ISSN 2029-0454

\title{
HUMAN RIGHTS AND CULTURAL IDENTITY
}

\author{
John-Stewart Gordon \\ Professor of Philosophy; Ph.D. \\ Faculty of Human Sciences, Vytautas Magnus University (Lithuania) \\ Contact information \\ Address: K. Donelaicio str. 52, LT-44244 Kaunas, Lithuania \\ Phone: +49 15732160163 \\ E-mail address: j.s.gordon@hmf.vdu.It
}

Received: November 15, 2015; reviews: 2; accepted: December 28, 2015.

\begin{abstract}
Universal human rights and particular cultural identities, which are relativistic by nature, seem to stand in conflict with each other. It is commonly suggested that the relativistic natures of cultural identities undermine universal human rights and that human rights might compromise particular cultural identities in a globalised world. This article examines this supposed clash and suggests that it is possible to frame a human rights approach in such a way that it becomes the starting point and constraining framework for all non-deficient cultural identities. In other words, it is possible to depict human rights in a culturally sensitive way so that universal human rights can meet the demands of a moderate version of meta-ethical relativism which acknowledges a small universal core of objectively true or false moral statements and avers that, beyond that small core, all other moral statements are neither objectively true nor false.
\end{abstract}

\section{KEYWORDS}

Human rights, cultural identity, clash of civilizations, moral universalism, moral relativism 


\section{NOTE}

This paper is based on two previous talks that I held at the Department of Philosophy at the University of Vilnius (16.06.2014) and at the international conference Identity and Globalization. Ethical Implications which was hosted by the University of Klaipeda (17.06.2014) and organized by the Department of Philosophy and Cultural Studies and the Council for Research in Values and Philosophy (USA). For the first talk, I would like to thank Vilius Dranseika and his students for their valuable comments; and for the second talk Dalia Stanciene and the participating colleagues for their feedback. 


\section{INTRODUCTION}

In this article, I attempt to depict the complex relation between human rights and cultural identity against the background of the so-called dichotomy between Western and non-Western cultural norms and values. The supposed tension between the universal demand of human rights, on one hand, and the relativistic nature of cultural identity on the other hand seems to undermine the possibility of a peaceful encounter between human rights and cultural identity in a globalised world. Many laypeople and scholars alike believe that the Western concept of human rights compromises, at least to some extent, the ways in which some nonWesterners conceive their own particular and valuable cultural features and lifestyles. Therefore, it is assumed that the influence of human rights on nonWestern cultures jeopardises the cultural identities of people living in non-Western settings. ${ }^{1}$

The first two main sections of this article briefly introduce the notions of human rights and cultural identity, respectively; the third part describes the clash between different cultural identities by appealing to some vital cases in the context of ethics, bioethics and politics. I then conclude by proposing a means of resolving these clashes, or what I call a "moderate" approach to culturally sensitive human rights that pays close attention to both perspectives.

\section{HUMAN RIGHTS: A BRIEF OVERVIEW}

What is a human right? At first sight, this question seems rather simple. But when we look more closely, we find that trying to answer this question properly causes one to confront a great complexity of vital ontological, epistemic, justificatory and moral issues concerning the notion of human rights. ${ }^{2}$ Of course, it is not possible to cover in a short essay the full range of issues entailed in the philosophy of human rights. Rather, I will start from generally uncontroversial assumptions about human rights and will then focus on the complex relation between human rights and cultural identity.

According to most scholars in the field, human rights are primarily moral rights of high priority that are universally valid, independent of any legal recognition by particular nation-states or of particular times and places. All human beings are endowed with these rights simply by virtue of their humanity. In this

\footnotetext{
${ }^{1}$ For example, Adamantia Pollis and Peter Schwab, "Human Rights: A Western Concept with Limited Applicability": 1; in: Adamantia Pollis and Peter Schwab, eds., Human Rights: Cultural and Ideological Perspectives (New York: Praeger, 1979).

2 John-Stewart Gordon, "Human Rights"; in: Duncan Pritchard, ed., Oxford Bibliographies in Philosophy (published online, 2015).
} 
respect, human rights are commonly seen as inborn, unalterable and inalienable. In addition, they are considered the minimal standards necessary to protect the most vital and precious interests and values of human beings-for example, their freedom, safety, equality, political participation and social security, to name just a few. This brief depiction of human rights seems to be uncontroversial. ${ }^{3}$

The more controversial issues concern attempts to broaden the range of the application of human rights. For example, first, some have sought to establish social, economic and cultural dimensions of human rights, ${ }^{4}$ whereas others have proposed granting "human" rights to sentient animals" (for example, "The Great Ape Project" by Peter Singer and Paola Cavalieri 1993) or declaring that nature has a right to protection. ${ }^{6}$ Such proposals are often referred to as an inflation of human rights. $^{7}$ Second, there is disagreement over the justification of human rights, which can rest on either a religious foundation, ${ }^{8}$ a general social agreement, ${ }^{9}$ an interestbased approach, ${ }^{10}$ an agency-based account, ${ }^{11}$ or still other perspectives such as those of "human dignity," 12 or "human well-being". ${ }^{13}$ There is currently no agreement about the justification or the ontological and epistemic nature of human rights. ${ }^{14}$

In view of these differences of opinion, why should we use a human rights approach in order to deal with important issues in our daily lives at all? In his famous pragmatist critique in Human Rights, Rationality, and Sentimentality (1993), ${ }^{15}$ Richard Rorty rejects any attempt at a rational justification of the

\footnotetext{
3 See Brian Orend, Human Rights: Concept and Context (Peterborough: Broadview Press, 2002); Jack Donelly, Universal Human Rights in Theory and Practice (New York: Cornell University Press, 2003); James Nickel, Making Sense of Human Rights (Oxford: Wiley-Blackwell, 2007).

4 Ellen F. Paul, Fred D. Miller, and Jeffrey Paul, Economic Rights (Cambridge: Cambridge University Press, 1992); James Crawford, The Rights of Peoples (Oxford: Clarendon Press, 1992); Abdullahi Ahmed An-Na'im, Human Rights in Cross-Cultural Perspectives: A Quest for Consensus (Philadelphia: University of Pennsylvania Press, 1995); Rob Buitenweg, Human Rights, Human Plights in a Global Village (Atlanta: Clarity Press, 2007).

${ }^{5}$ For example, Sue Donaldson and Will Kymlicka, Zoopolis. A Political Theory of Animal Rights (Oxford: Oxford University Press, 2013).

${ }^{6}$ Sumudu Atapattu, Human Rights Approaches to Climate Change: Challenges and Opportunities (New York: Routledge, 2015).

7 Maurice Cranston, What Are Human Rights? (London: Bodley Head, 1973); Maurice Cranston, "Human Rights, Real and Supposed": 163; in: D. Raphael, ed., Political Theory and the Rights of Man (London: Indiana University Press, 1967).

8 Michael Perry, The Idea of Human Rights: Four Inquiries (Oxford: Oxford University Press, 2000).

9 John Locke, Two Treatises of Government, ed. Peter Laslett (Cambridge: Cambridge University Press, 1960); John Rawls, The Law of Peoples (Cambridge: Harvard University Press, 1999).

10 Joseph Raz, The Morality of Freedom (Oxford: Oxford University Press, 1986); Allen Buchanan, Justice, Legitimacy, and Self-Determination: Moral Foundations for International Law (Oxford: Oxford University Press, 2004); James Nickel, supra note 3; James Griffin, On Human Rights (Oxford: Oxford University Press, 2009).

${ }_{11}$ Alan Gewirth, Human Rights: Essays on Justification and Application (Chicago: University of Chicago Press, 1982); Michael Boylan, Natural Human Rights: A Theory (Cambridge: Cambridge University Press, 2014).

12 Gregory Vlastos, "Justice and Equality"; in: J. Waldron, ed., Theories of Rights (Oxford: Oxford University Press, 1984).

${ }^{13}$ William Talbott, What Rights Should Be Universal? (Oxford: Oxford University Press, 2005).

14 John-Stewart Gordon, supra note 2.

15 Richard Rorty, "Human Rights, Rationality and Sentimentality": 111; in: Stephen Shute and Susan Hurley, eds., On Human Rights: The Oxford Amnesty Lectures 1993 (New York: Basic Books, 1993).
} 
theoretical foundations of human rights. Nonetheless, he acknowledges the practical importance of having a human rights culture grounded on shared sentiments in order to promote empathy with other people. Despite the on-going theoretical and academic debates about the nature of human rights, there are at least four main reasons why one should take human rights seriously in practical matters. ${ }^{16}$

\section{(a) Force of language}

The language of human rights has a great rhetorical, moral and popular force. ${ }^{17}$ Violations of human rights are seen as serious incidents that call for immediate action. The vulnerability of human beings to infringements on their lives and liberties justifies actions designed to ensure their protection (for example, Universal Declaration of Human Rights in 1948).

(b) Established legal framework

Human rights instruments already exist within the established framework of international law, including treaties, agreements and conventions. ${ }^{18}$ These established provisions can be used to help in solving ethical conflicts on the international or national level.

\section{(c) Universality}

The universality of human rights facilitates the establishment of universal moral norms for analysing and responding to cultural challenges. A global ethics necessarily needs to appeal to a (minimal) universal standard, or lingua franca, in order to solve cross-cultural problems.

\section{(d) Relation of rights and health}

There is a close relationship between biomedicine and the most basic human rights such as the right to life, the right to physical integrity, and the right to healthcare and to healthcare resources. ${ }^{19}$ This consideration becomes particularly relevant when we consider the potential collision between human rights and certain cultural practices, such as female genital circumcision.

\footnotetext{
16 See John-Stewart Gordon, "Human rights in bioethics: theoretical and applied," Ethical Theory and Moral Practice 15/3 (2012): 286.

17 Robert Baker, "Bioethics and human rights: a historical perspective," Camb Q Healthc Ethics 10 (2001); L. Knowles, "The lingua franca of human rights and the rise of global bioethics," Camb Q Healthc Ethics 10(3) (2001).

18 Robert Baker, supra note 17; L. Knowles, supra note 17.

19 Richard Ashcroft, "The troubled relationship between bioethics and human rights": 31 ; in: $M$. Freeman, ed., Law and Bioethics (Oxford, University College London, 2008); John-Stewart Gordon, "Poverty, human rights and just distribution"; in: M. Boylan, ed., International Public Health Policy and Ethics (Berlin: Springer, 2008); J. Arras and E. Fenton, "Bioethics and human rights: access to healthrelated goods," Hastings Cent Rep 29 (2009); Efrat, Ram-Tiktin, "The right to health care as a right to basic human functional capabilities": 1; in: John-Stewart Gordon, ed., Special Issue: Human Rights in Bioethics (Springer, published online 2012).
} 


\section{WHAT IS CULTURAL IDENTITY?}

The notion of cultural identity is complex and opaque. In this section I attempt to flesh out a common-sense meaning of the term. Let us first begin by considering what identity means before we move on to examine the notion of cultural identity. In the context of individuals and groups of people, the term identity usually denotes particular traits or properties that are characteristic of the self-conception of those individuals or groups. Such traits as language, religion, education, social status, ethnicity and gender are important factors in both one's own self-conception and how other people see us. Thus, to acknowledge one's own identity presupposes at least two different perspectives. The first perspective is the individual self that is constituted by self-reference, and the second perspective is the confrontation with others that makes it, in general, possible for us to see ourselves as distinct entities in the first place. It seems clear that each individual self is not isolated (i.e. none of us is an island) but, rather, interacts with the social or collective self, and furthermore that the self is deeply embedded in a social setting that strongly contributes to the self-perception of each individual. Whether this phenomenon-that we perceive ourselves partly by reference to the social setting around us-is a good or a bad thing is another issue entirely.

\subsection{CULTURAL IDENTITY}

The concept of cultural identity, then, can be understood as an institutionalised and, more or less, unified vision or worldview as to how people at a certain particular place and time in history should live together, one that can be clearly distinguished from other ways of living. Cultural identity is necessarily bound to a social group and a certain particular place, such as a nation-state (e.g. Ukraine) or a particular region within a nation-state (e.g. Crimea). In addition, it typically comprises vital traits, such as a shared language, place of residence, religion, values and traditions, and often ethnicity as important means of defining the particular cultural identity. However, my contention at this point is not that cultural identities are always and completely determined by these factors, but rather that such aspects are commonly seen as relevant in describing the notion of cultural identity. Individuals who view themselves as members of a particular cultural identity are not thereby required to comply with every defining aspect of that identity; they may actually share only parts of it. In other words, cultural identities are not necessarily homogeneous but can also be heterogeneous by nature; in fact, the latter seems to be the rule and not the exception. 


\subsection{A CLASH OF CIVILISATIONS?}

One vital question today concerns whether distinct cultural identities will persist in the future, given the impact of globalisation. Many people fear that their particular and valued national identities will vanish into thin air, replaced by some form of abstract and unfamiliar supranational identity. Some non-Westerners fear being subsumed within Western cultures; meanwhile, some Europeans feel that they and their cultural identities could eventually be overwhelmed by migrations from North Africa and the Middle East. Whether the process of globalisation will lead to a so-called clash of civilisations as groups seek to maintain and fight for their particular cultural identities is considered in The Clash of Civilizations and the Remaking of World Order (1996), by the famous American political scientist Samuel P. Huntington. ${ }^{20}$ Huntington's main thesis is that, since the Cold War, world politics has been determined not by political, ideological or economic conflicts but rather by conflicts between members of different cultures-that is, between cultural identities. The emphasis on one's own cultural identity becomes stronger against the background of globalisation, because people feel a greater need to distinguish themselves from others who do not belong to their own culture. Huntington argues that each major cultural centre (i.e. the Western world, the Islamic world, India, the Slavic-Orthodox Russian territory, China, and Japan) comprises basic values that are, in principle, incompatible with the basic values of other cultures, and that therefore a global conflict-a clash of civilisations-is inevitable.

There are at least two different but related responses to Huntington's argument, both of which show convincingly that such a clash of civilisations is most unlikely. First, there are much greater differences concerning issues of inequality and individualism between Islamic countries than between Islamic and non-Islamic countries of different cultural heritages. ${ }^{21}$ Hence, the underlying thesis of a unified cultural identity among nation-states or groups of nation-states cannot be sustained. Moreover, empirically speaking, there is no incompatible contrast between the basic social values of the main cultural identities mentioned by Huntington. On the contrary, substantial similarities can be identified across all cultures. ${ }^{22}$ Second, Amartya Sen (2007) has objected to Huntington's line of reasoning by observing that it is, for example, completely possible for an individual to claim to be a US citizen of Caribbean heritage with African ancestors, a Christian, a liberal, a woman, a vegetarian, a long-distance runner, a heterosexual and a

\footnotetext{
20 Samuel P Huntington, The Clash of Civilizations and the Remaking of World Order (New York: Touchstone, 1996).

21 Thomas Meyer, Identitätspolitik. Vom Missbrauch des kulturellen Unterschieds (Frankfurt am Main: Suhrkamp, 2002).

22 Ibid.
} 
tennis fan. ${ }^{23}$ If I understand Sen's intent correctly, his argument is that people differ in many different ways, and that therefore it is impossible to make any serious prognosis about the behaviour of culturally defined collectives based on their cultural identities. We simply don't know.

Huntington's ideas have gained popularity in recent years against the background of the mass migrations of people from North Africa and the Middle East and the consequent revitalization and rise of nationalist parties in Europe. These right-wing movements have warned that Europeans' culture and way of living will decline if the mass migration of people with "inferior" cultural identities does not stop. Quite alarmingly, this nationalist propaganda has not fallen on deaf ears, but has found many sympathisers in European societies. For example, in Germany these nationalist parties have contributed to an atmosphere in which politically motivated crimes are committed on an almost daily basis (such as the burning of hundreds of refugee hostels across Germany in 2015 and the increasing violence against people believed to be of foreign background). Admittedly, these incidents do not prove that a deep-rooted clash of civilisations is occurring, but they do indicate that many fear the social and economic consequences of mass migration and are seduced by nationalist rhetoric that plays on these popular fears.

\section{THE CLASH OF CULTURAL IDENTITIES}

Let us now turn to real-life clashes between cultural identities. I will begin by briefly describing five paradigmatic cases to highlight some problems concerning the relations between different cultural identities. These thought-provoking examples not only show the obvious, namely that different cultural identities may clash, but also are evaluated against the background of human rights, which are the starting point and constraining framework of all non-deficient cultural identities.

To define this concept: deficient cultural identities are, by virtue of their very nature, completely incompatible with the human rights agenda. For example, the so-called Pirate's Creed of Ethics was the "moral" code of an organization of low and deceitful people whose main business was to rob, to murder, to gain profit by illegal means, and to set their members free from any other social, political, and moral standards of a given community. By way of comparison, a particular cultural identity might contain immoral features from a human rights perspective - for example, it might forcefully advocate female genital circumcision - but might still be considered a non-deficient cultural identity since, overall, it is still compatible

23 Amartya Sen, Identity and Violence. The Illusion of Destiny (New York, London: W. W. Norton \& Company, 2007). The crucial idea that people are part of different (social) roles has also been highlighted by neo-Kantian philosopher Christine Korsgaard in The Sources of Normativity (Christine Korsgaard, The Sources of Normativity (Cambridge: Cambridge University Press, 1996)). 
with the human rights agenda, which can be seen as the gold standard for evaluating the clashes between different cultural identities (as further discussed below).

\subsection{FIVE CASES}

(a) Colonialism by Western "high" culture

At the end of the 19th century, the most powerful European countries, such as England, Belgium, the Netherlands, France and Germany, started to colonise the African continent. Within 20 to 30 years, they occupied almost 90 percent of the land. Adhering to a particular understanding of what "culture" meant, the colonial powers purportedly sought to "help" the African people to overcome their so-called "primitive" culture so that they could enjoy the gifts of Western "high" culture, including education and a proper infrastructure. The underlying motive of the European governments, however, was to harvest the natural resources and cheap labour available in Africa for economic profit. The initially stated goals of introducing the African people to so-called high culture turned into impositions of colonialism that involved the enslavement of many African peoples, millions of deaths, and widespread torture (e.g. during Belgium's reign in the Congo). The colonial powers with their dominant Western cultural identity tried to suppress the supposedly inferior cultural identities of many African tribes. The Westerners looked down on them because they thought, simply speaking, that the Western cultural identity was superior and should be adopted no matter what.

(b) Female genital circumcision: a harmful, idiosyncratic practice

It is estimated that about 200 million women around the world are circumcised (the growth rate lies at 4 to 5 million women per year). The social practice of female genital circumcision is performed in many African countries, in some Arab countries such as Yemen and Oman, and by some Muslim groups in Pakistan, Indonesia, Europe, North America, Malaysia and the Philippines. ${ }^{24}$ Those cultural groups who favour this practice present several arguments on its behalf: performance of religious duties, promoting group identity, cleanliness and health, preserving virginity (i.e. to protect the family's honour), promoting monogamy and increasing the sexual pleasure of men. On the other hand, proponents of the human rights agenda claim that female genital circumcision can cause serious harm and hence is a violation of the human right not to be harmed. The immediate health-related problems resulting from female circumcision include death, infection,

${ }^{24}$ There are three main types of female genital circumcision. The first type involves removal of the clitoris foreskin, the second entails full removal of the inner labia, and the third includes full removal of the clitoris, the inner labia, parts of the labia majora, and the clitoris foreskin. All three forms are common. 
gangrene, and post-traumatic stress; mid-term problems include incontinence, pelvic inflammation, and post-traumatic stress; long-term problems include complications or difficulties in sexual intercourse or in giving birth, along with posttraumatic stress. See, for example, Macklin (1999) ${ }^{25}$ and Kopelman (2001). ${ }^{26}$ They also consider the practice to be a violation of personal autonomy.

\section{(c) Ukraine: the clash of different cultural identities}

The recent political events in Ukraine can be described as a conflict between people who hold different cultural identities. The Russian majority (about 60 percent of residents) in Crimea sought to separate from Ukraine and to become part of Russia. They were supported by some non-Russians who believed that Russia might be more able than Ukraine to promote the social and economic welfare of Crimea (a contention that remains open to debate). Many Ukrainian people in Crimea and elsewhere who have a more Western orientation have denounced the proponents of the Crimean revolution and attempted to revoke the so-called annexation of Crimea by Russia. Without too much oversimplification, one can accurately say that in this conflict a minority within a culturally diverse country sought to secure its freedom from the majority by detaching their particular place (Crimea) from the home country (Ukraine). Does a cultural minority have a right to do so?

(d) The Sinti and Roma: the largest neglected minority in Europe

The case of the Sinti and Roma and their particular cultural identity is particularly enlightening because in this instance Westerners have argued on behalf of restricting the free movement of Eastern European Sinti and Roma in order to prevent their infiltration of Western Europe. Sinti and Roma currently represent the largest European ethnic minority, with perhaps 10 to 12 million members. About four million of them live in Bulgaria, Romania, Hungary and Slovakia, and they are also present in other Eastern European countries, especially Serbia and Macedonia. However, not only in their home countries but also in the rest of Europe, Sinti and Roma are marginalised, stigmatised and discriminated against by virtue of their particular cultural identity. This is obviously a serious violation of their human rights. The vital question here is whether a majority group can restrict the free movement of a minority group simply because it thinks that the minority group's particular way of living is somewhat inferior and that the minority group might molest other people (e.g. by begging). This limitation of free movement is usually supported by unjustified suggestions of increased theft that might occur if Sinti and

\footnotetext{
25 Ruth Macklin, Against Relativism. Cultural Diversity and the Search for Ethical Universals in Medicine (New York, Oxford: Oxford University Press, 1999).

${ }^{26}$ Loretta Kopelman, "Female circumcision/genital mutilation and ethical relativism": 307; in: Paul K. Moser and Thomas L. Carson, eds., Moral Relativism: A Reader (Oxford: Oxford University Press, 2001).
} 
Roma lived in the vicinity. The brutal and sad fact is that rejection of their cultural identity has caused them to become repeated victims of violence, neglect (e.g. denial of educational opportunities) and genocide (e.g. at the hands of the Nazis in Germany) during their history.

(e) Mass migration in 2015: the major test case for the unity of democratic Europe

Migrations can involve at least three distinct categories of people. Asylum seekers generally migrate because they are politically prosecuted in their home countries, people fleeing from war are called refugees, and the term migrant is usually reserved for those who migrate for social and economic reasons. Of course, these motives can overlap and the true motive(s) for migration can sometimes remain unclear.

The mass migrations from North Africa and the Middle East to Europe during 2015 have included people from all three categories: people seeking asylum due to political prosecutions in Syria and religious persecution by the Islamic State, refugees from the Syrian civil war, and migrants who want to work abroad in order to improve their socio-economic conditions. The above-mentioned changes in European attitudes towards migrants pose a serious threat to the integrity and unity of democratic Europe by undermining the core values of solidarity and concern for the general welfare. The common underlying motif of the nationalist stance is that migration undermines the homogeneity of the home community and creates unemployment. These concerns are reinforced by general prejudices, such as the beliefs that migrants are all criminals, that they prey on the social systems of wealthy European countries, that they are somehow inferior human beings, or that they wish to Islamise Europe (e.g. by installing Sharia as common law). The decisive question is whether one should-legally or morally-allow a nationalist minority, who stand for a particular idiosyncratic and dehumanising cultural identity, to fight against and thereby undermine the democratic cultural identities of political systems in Europe. Should the human right to freedom of speech protect views that nurture a hatred of foreigners and thereby jeopardise the European core values of solidarity and general welfare?

\subsection{SOME BRIEF OBSERVATIONS}

What can we learn from the above-mentioned cases concerning, first, the relations between different cultural identities and, second, between human rights and (other) cultural identities? The cases reveal that different cultural identities 
often clash for idiosyncratic and unjustified reasons. To lay the groundwork for my own culturally sensitive approach to human rights, I propose four observations.

(a) The so-called "other" is often seen as inferior in terms of culture, economy and the social sphere (for example, in the cases of colonialism, the Sinti and Roma, and migrants from North Africa and the Middle East).

(b) Some particular cultural identities are seen as a social threat to traditional ways of living by virtue of their disruptive potential for the dominating cultural identity (Sinti and Roma, Ukraine, and migrants from North Africa and the Middle East).

(c) The presence of differing cultural identities is sometimes perceived as jeopardising social harmony because it causes the majority to feel unsafe, and therefore majorities sometimes do not welcome other dissenting cultural identities that might undermine their way of living (Sinti and Roma, migrants from North Africa and the Middle East).

(d) Finally, some cases present not only a clash of different cultural identities, but also clear violations of the timeless human rights agenda (female genital circumcision, colonialism).

In general, non-Western cultural identities such as the Sinti and Roma who do not conform to the dominating cultural identity frequently risk being shunned, marginalised, neglected, discriminated against and even murdered. With rare exceptions, minority groups holding a particular cultural identity do not seek to convince the majority to adopt their cultural identity (for example, the Sinti and Roma do not recruit Europeans to adopt their lifestyle). Usually they want simply to live in peace with other cultural identities, although there are a few more aggressive minorities such as the so-called Islamic State. ${ }^{27}$ In these clashes between cultural identities, members of the minority group are often treated as inferior, an experience that is devastating for their own self-conception and for their general ability to live a good life. It seems clear that acts that degrade and humiliate other people because of their dissenting cultural identity are serious violations of human rights and therefore should be banned and punished. Of course, this does not mean that different cultural groups have a duty to become close friends; rather, this premise simply requires people of different cultural identities to live in peace with one another and not to stigmatise or attack those who do not share their cultural identity. Anthropologist and lawyer Alison D.

\footnotetext{
27 The key distinction seems to be between ethnic and ideologically motivated groups. The latter typegroups with a religious or political agenda-frequently do indeed wish to impose their worldview on others. The former sometimes do-resulting in serious ethnic conflict in such places as Serbia and Rwanda-but generally the minority group recognises that a peaceful coexistence is the best they can hope for.
} 
Renteln ${ }^{28}$ offers a persuasive explanation as to why nation-states are often uncomfortable with different cultural identities.

National governments are fearful of multiculturalism because it exposes the fiction of any national identity. If there is uncertainty about the national identity, then the presence of different ethnic groups causes anxiety because it may call the national identity into question. The ambivalence and unease of legal actors demonstrate this deep-seated fear of the consequences of recognizing diverse ways of life. That unconventional lifestyles seem so threatening should give us pause. ${ }^{29}$

Table 1. The Human Rights Agenda as Applied to Five Cases

\begin{tabular}{|c|c|}
\hline Colonialism & $\begin{array}{ll}\text { - } & \text { Right to be free from discrimination. } \\
\text { - } & \text { Right to be free from slavery. } \\
\text { - } & \text { Right of self-determination. } \\
\text { - } & \text { Right of autonomy. } \\
& \text { Realth and bodily integrity. }\end{array}$ \\
\hline $\begin{array}{l}\text { Female genital } \\
\text { circumcision }\end{array}$ & $\begin{array}{ll}\text { - } & \text { Right of autonomy. } \\
\text { - } & \text { Right to health and bodily integrity. }\end{array}$ \\
\hline Ukraine & $\begin{array}{ll}-\quad & \text { Right of self-determination. } \\
\text { - } & \text { Respect for cultural minorities. }\end{array}$ \\
\hline Sinti and Roma & $\begin{array}{ll}\text { - } & \text { Right of self-determination. } \\
\text { - } & \text { Right to equal education. } \\
\text { Right to be free from discrimination. }\end{array}$ \\
\hline Mass migration & $\begin{array}{ll}\text { - } & \text { Right to be free from discrimination. } \\
\text { - } & \text { Right to freedom of movement. } \\
\text { Respect for cultural minorities. }\end{array}$ \\
\hline
\end{tabular}

In addition, the above-mentioned cases also illustrate the apparent clashes between the overarching human rights agenda and some cultural identities, not simply clashes between different cultural identities. Table 1 describes the most significant human rights that are violated in each of our five examples. Through this comparison, we can perceive and acknowledge the pre-eminence widely accorded to the human rights agenda as the background against which all cultural identities should be evaluated. Some may object that the human rights agenda, which proposes to protect all ethnic groups and other minorities from mistreatment, is itself a cultural identity with the same ontological standing as other cultural identities. However, this is not the case. Rather, the human rights agenda provides the very foundation for all other non-deficient cultural identities. It can be seen as both a starting point and a constraining framework, and for this reason it enjoys a special status among cultural identities. The next section will outline an argument for this claim.

${ }^{28}$ Alison Dundes Renteln, The Cultural Defense (Oxford, New York: Oxford University Press, 2004).

29 Ibid., 218. 


\section{CULTURALLY SENSITIVE HUMAN RIGHTS: A MODERATE APPROACH}

\subsection{THREE TYPES OF MORAL RELATIVISM ${ }^{30}$}

It is common to distinguish three types of moral relativism: descriptive or cultural relativism, meta-ethical relativism, and normative (moral) relativism. I will describe each of these three concepts previously to provide a basis for the subsequent analysis.

\section{(a) Cultural relativism}

Proponents of cultural relativism claim that culture is relative to societies, and that this fact can be substantiated by empirical observation. In other words, if you look around the world you see various societies with different cultures, idiosyncratic norms and traditions. For example, the famous anthropologist Ruth Benedict claims that "morality differs in every society, and is a convenient term for socially approved habit". ${ }^{31}$ In addition-and less convincingly-many anthropologists go beyond mere empirical observation and argue that one should not judge any particular moral code or parts of a moral code from an external perspective, even if that code contains practices that others deem immoral, such as female genital circumcision. Their argument is that morality is itself relative and depends on the social context. Since there are different societies, they contend, there are also different moral codes, all of which can be legitimate in their own particular societies. $^{32}$

\section{(b) Meta-ethical relativism}

Meta-ethical relativism expresses a viewpoint concerning the ontological nature of moral statements. There are two common versions of meta-ethical relativism. The more extreme version declares that moral statements are neither objectively true nor false. ${ }^{33}$ The more moderate version acknowledges a small universal core of objectively true or false moral statements and avers that, beyond that small core, all other moral statements are neither objectively true nor false.

\footnotetext{
30 For a more detailed discussion see T. Carson and P. Moser, Moral Relativism. A Reader. (Oxford: Oxford University Press, 2001); James Rachels, "The challenge of cultural relativism"; in: Paul K. Moser and Thomas L. Carson, eds., Moral Relativism: A Reader (Oxford: Oxford University Press, 2001).

31 Ruth Benedict, Patterns of Culture (Boston: Houghton Mifflin Company, 1934); cited in Ruth Maklin, supra note 25,31 .

32 For example, Renteln has examined the idea of "cultural defense" in US law. She concludes: "Culture shapes individual identity in crucial ways. The failure of the law to recognize this has resulted in injustices. Until the right to culture is understood to be a basic human right, individuals will continue to be told that they must become assimilated, that their background is 'irrelevant,' and that there is only one correct way to behave. In a culturally diverse society, it is necessary that individuals be permitted to pursue their own life plans without interference from the government. Unless the cultural traditions at issue involve irreparable harm, they should be allowed" (Alison Dundes Renteln, supra note 28, 219).

${ }^{33}$ See John L. Mackie, Ethics. Inventing Right and Wrong (London: Harmondsworth, 1977).
} 


\section{(c) Normative moral relativism}

The third type of relativism is normative moral relativism, which seeks to define when individuals are subject to moral obligations. This type of relativism also comes in different versions. Two common standpoints are referred to as social relativism and individual relativism. Social relativism claims that an action is morally obligatory for a person if the action is prescribed by the moral principles of a given society; this perspective is typical of social contract theories. Proponents of individual relativism (or solipsism) believe that an action is morally obligatory for a person if it is required by the moral principles of the person in question.

Can the general idea of universal human rights be placed within any version of moral relativism without jeopardising its very nature? From a human rights perspective, one could argue as follows. First, it is empirically correct that the world consists of many different societies with divergent cultural settings. But this fact is fully compatible with the idea of human rights. The critical point of conflict involves the subsequent claim by some cultural relativists such as Ruth Benedict that the normative claims of morality depend exclusively on the particular society. This claim stands in stark contrast with the claim that human rights are universal by nature and not dependent on particular cultures or societies. In contrast, a human rights approach is most likely compatible with meta-ethical relativism in its moderate version, though not in its extreme version. It seems plausible that, if we agree on the existence of a core of moral statements that are objectively true or false, that core might also encompass universal human rights. In this understanding, human rights would form a sub-class of those moral statements that are, by nature, objectively true or false. At the same time, however, a proponent of universal human rights could acknowledge the existence of a different class of moral statements that are, by nature, neither objectively true nor false.

Finally, with regard to the third category of relativism described above, social and individual relativism are incompatible with universal human rights. One might claim, perhaps, that it should be possible to simply extend the size of a particular society so that it becomes a world society with only one set of moral principles that governs all people (as the ancient Stoics proposed). But this would vitiate the very meaning of relativism, since it would cause relativism to vanish into thin air and be turned into universalism. Hence it follows, not surprisingly, that universal human rights are, by nature, incompatible with normative moral relativism unless one additionally claims that the core of moral statements contained in the moderate 
version of meta-ethical relativism should also be effective in the area of normative moral relativism. ${ }^{34}$

\subsection{ON THE SPECIAL STATUS OF THE HUMAN RIGHTS AGENDA}

Critics have often depicted the idea of human rights as a biased Western creation that discriminates against non-Western cultures. Some such objectors view the human rights agenda as a form of ethical imperialism aimed at changing valuable and highly esteemed local cultural practices (e.g. female genital circumcision) that stand in contrast to the Western way of life. Similarly, many adherents of moral relativism seem to believe that all (or most) cultural identities have the same moral status and should be equally respected regardless of their content. This, however, is a misleading claim (for example, Rachels 2001 who refutes such a misleading claim ${ }^{35}$ ).

Proponents of universal human rights contend that cultural identities differ in their moral status depending on how they treat their own members and nonmembers, animals, and nature. From this perspective, it does make a moral difference whether a group of people experiences discrimination due to contingent facts such as gender, ethnicity and impairment. It does make a moral difference whether women are forced to have their genitals circumcised so that they can meet the social standards of a male-centred society, thereby exposing themselves to a dubious and severely harmful practice. And it does make a moral difference whether a society enslaves some of its people or whether all citizens are entitled to live freely in peace and harmony.

The human rights agenda sets a minimal universal standard as to how all people should treat each other, namely in a respectable, fair and equal way. Whether this way of articulating human rights originated in the West is of no relevance. Had they been discovered by any non-Western culture, they would be just as true and reasonable as they are now. All cultural identities must be evaluated by the human rights agenda. As Figure 1 depicts, human rights (HR) are the starting point and constraining framework of a dialectical relationship between the universal cultural identity of human rights and all non-deficient cultural identities. To use the metaphor of a comet, human rights can be seen as the body of the comet-the starting point-and the borders of the tail can be viewed as the limits of the constraining framework. This means that all cultural identities (CIs) located outside the tail are deficient-for example, the cultural identity of

\footnotetext{
34 Whether there exists any systematic link between meta-ethics and normative ethics and, if so, to what extent is a matter of considerable debate, which I cannot describe here due to space limitations.

35 James Rachels, supra note 30: 53.
} 
slaveholders in the 19th-century American South or the cultural identity of a pirates' creed of ethics. All non-deficient cultural identities, which are in accord with human rights, are located within the borders of the tail $\left(\mathrm{CI}_{a}, \mathrm{CI}_{b}, \mathrm{CI}_{c}\right)$. Furthermore, cultural identities can conceivably be distinguished from each other in relation to the extent to which they make possible the full enjoyment of human rights. The different positions of the three non-deficient cultural identities in Figure 1 illustrate this point: $\mathrm{CI}_{b}$ is placed highest to indicate that it comes closest to the full realisation of universal human rights. ${ }^{36}$

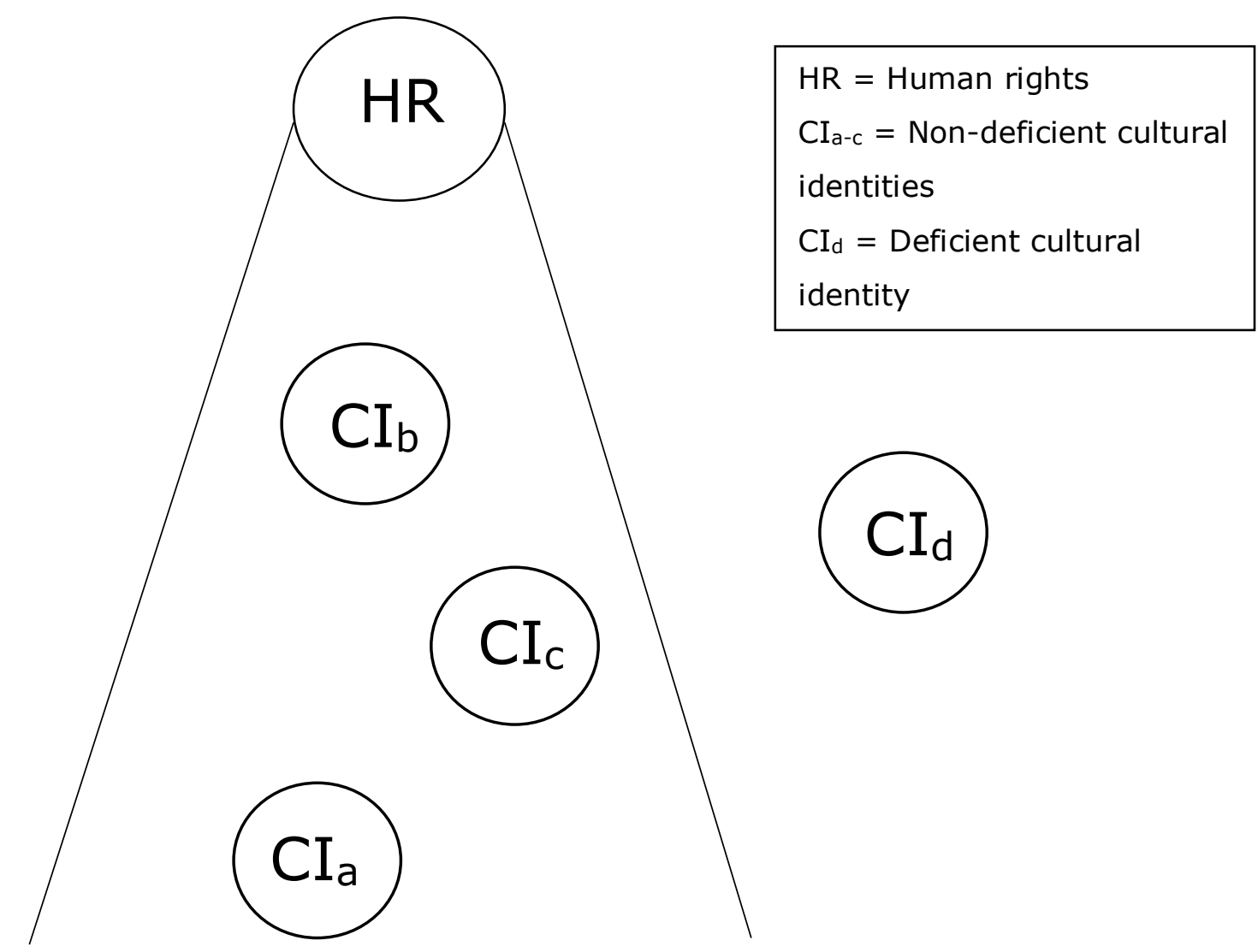

Figure 1: Human Rights and Cultural Identities

In other words, a society whose cultural identity fully endorses the institution of slavery or that discriminates against women is deficient, morally speaking. As empirical evidence amply demonstrates, the human rights agenda is flexible enough to allow for various different expressions within an acceptable range of

36 John-Stewart Gordon, "Global ethics and principlism," Kennedy Institute of Ethics Journal 21/3 (2011): 256-261; in particular: 256-257. 
possibilities. ${ }^{37}$ In this respect, human rights are not a threat to cultural identities unless those identities undermine the most vital and precious basic interests of human beings (i.e. safety, equality, freedom and bodily integrity).

Appealing to the universal human rights agenda can solve conflicts between different cultural identities. Two methods, specification and balancing, can be used to this end. The method of specification reduces the indeterminacy of the rather abstract and universal concept of human rights by adding relevant empirical data; this could lead to different but valid specifications of a given universal human right depending on the given context. The method of balancing is concerned with determining the reasons for choosing one particular specification of a given human right over another. Both methods are already well-known in the context of bioethics, where they have long been applied, such as by Beauchamp and Childress in their Principles of Biomedical Ethics (2009), 38 to solve problems between different particular moralities by appealing to the idea of a common morality. ${ }^{39}$ Beauchamp and Childress ${ }^{40}$ define the notion of common morality as a "set of norms shared by all persons committed to morality. The common morality is not merely a morality, in contrast to other moralities. The common morality is applicable to all persons in all places, and we rightly judge all human conduct by its standards" 41 The very idea of seeing the human rights agenda as the foundation of all cultural identities goes back to Beauchamp and Childress's understanding of a common morality. Likewise, universal human rights (as a basic cultural identity), are not merely one cultural identity in competition with others; rather, they embody an overarching set of principles and the gold standard against which all cultural identities are judged.

How would the methods of specification and balancing work in cases where human rights and cultural identities clash? How should these rather broad and sometimes discordant concepts be reconciled so as to pay proper respect to both notions? The above-mentioned, rather theoretical considerations can be illustrated by the case of female genital circumcision, which was briefly discussed above. For the sake of argument, let us assume that female genital circumcision fulfils some important societal needs that have been passed on from one generation to another. Perhaps it (a) serves as an important initiation ceremony marking the point at which girls become women (which is commonly seen as indispensable among many

37 See Simon Caney, "Human Rights, Compatibility and Diverse Cultures," Critical Review of International Social and Political Philosophy 3.1 (2000); Simon Caney and Peter Jones, Human Rights and Global Diversity (London and Portland: Frank Cass Publishers, 2001).

38 Tom Beauchamp and James Childress, Principles of Biomedical Ethics (Oxford: Oxford University Press, 2009).

39 See John-Stewart Gordon, Oliver Rauprich, and Jochen Vollmann, "Applying the Four-Principle Approach," Bioethics 25/6 (2011).

40 Tom Beauchamp and James Childress, supra note 38.

41 Ibid. 3. 
societies that practise this social institution), (b) supports faithfulness in marriage (by helping to discourage extramarital affairs), and (c) sets an example of religious purity (to fulfil the particular religious needs of a given community). These main communal needs, along with other considerations, outweigh and thus justify, for its practitioners, the infringement upon the right of individual autonomy and the right to health and bodily integrity, which are traditionally upheld by the human rights agenda. Additionally, however, the actual execution of a female genital circumcision can cause excruciating pain for the rather young girls who undergo it; some even die from health-related complications following this procedure.

Against this background, is it possible to reconcile the dangerous and painful social practice of female genital circumcision with the universal demands of the human rights agenda? Due to space limitations, I will only briefly examine this issue with respect to the moderate approach.

\section{(a) The principle of autonomy}

The principle of autonomy is cited by both sides, i.e. proponents and critics of female genital circumcision. However, they articulate this universal principle in very different ways. Westerners tend to specify the principle of autonomy in mainly individualistic terms, whereas many communities in which female genital circumcision is practised adhere to a family-oriented understanding of the concept. One way to deal with this situation is to further refine the types of cases which might require an individual's consent instead of the traditional family-oriented consent. Here, one could argue in the context of the moderate approach that whenever a particular tradition requires severe medical interventions that might cause serious health-related problems or even death, the individual's personal consent should be requested as the only means to adequately satisfy the principle of autonomy under such conditions. This would honour the particular cultural tradition in most cases while, at the same time, specifying in greater detail what types of circumstances might require the individual's and not just the family's consent. That is because only an autonomous individual should give consent with respect to far-reaching medical procedures that might cause severe long-term problems and even death.

(b) Initiation ceremony for girls to become women

In many different cultures, Western and non-Western alike, rituals are practised to mark a teenager's transition into a respected adult. Female genital circumcision is usually practised on young (sometimes very young) females who lack an understanding of how this medical intervention could affect their health. Becoming an adult - regardless of what culture one is in - should presuppose that the person is sufficiently mature to fully understand the potential consequences of a 
painful initiation ceremony. Given that the procedure presents severe risks - unlike the comparable Western social practices - one should wait until the person is fully able to grasp the health-related consequences of female genital circumcision. If a teenager is old enough to make a well-informed individual decision, then one should respect this as good evidence of adulthood.

\section{(c) Degree of female genital circumcision}

We have mentioned above that there are currently three main types of female genital circumcision. The first type involves removal of the clitoris foreskin, the second entails full removal of the inner labia, and the third includes full removal of the clitoris, the inner labia, parts of the labia majora, and the clitoris foreskin. All three forms are common. The moderate approach to human rights is culturally sensitive in acknowledging the idea that different cultural identities might fit under the human rights umbrella without undermining the universal demands of the (Western) human rights agenda. A culturally moderate approach could maintain and respect the idea that female genital circumcision is important to a particular community, for the reasons explained above, while also insisting that health-related risks must be minimised - for example, by ensuring that the circumcision is conducted by medical experts using scalpels, not pieces of broken glass or machetes, in order to avoid infection or the impact of unprofessional surgery. One may conclude that only the first type female circumcision, limited to removing the clitoris foreskin, is in accord with the human rights agenda. That would respect the particular cultural tradition and also each individual's right to bodily integrity and health.

This brief application of the moderate approach to human rights shows how it seeks to respect particular, idiosyncratic traditions on one hand (in this case, female genital circumcision) and, on the other hand, to uphold the human rights agenda as a universal standard of moral demands for the global community of multiple cultural identities. We have seen that sober, careful specification and balancing of principles and concepts are of utmost importance in the context of the moderate approach. However, one might still raise the question: in exactly what sense do human rights serve as a framework for cultural identities? This paper defends the view that human rights are the starting point and constraining framework for all non-deficient cultural identities. That means that cultural identities are, morally speaking, held accountable for their content with respect to the universal demands of the human rights agenda. For example, the second and third types of female genital circumcision clearly represent a gross violation of women's rights, whereas the first type could be harmonised with the moderate approach to human rights as a justified expression of a particular cultural tradition. 
It is a justified expression because the demands of both sensitivity to a given cultural identity and human rights are met sufficiently. The overall idea, however, is not that we are supposed to fully understand and appreciate the meaning of every social institution of a given cultural identity, but that we should respect all cultural identities that are in accord with the human rights agenda, regardless of our own particular worldview.

\section{CONCLUSIONS}

As elucidated above, the moderate approach to universal human rights is compatible with the moderate version of meta-ethical relativism, the idea that there exists a small universal core of objectively true or false moral statements. This small and universal core is the starting point and constraining framework for all non-deficient cultural identities. The human rights agenda forms the very foundation of an ideal just society. This article did not deal with the question of the justification of specific human rights as such; that would have been a different project. Rather, it promoted a conception of universal human rights by which all cultural identities can and should be evaluated. The further development of culturally sensitive human rights is an on-going and demanding project that requires careful attention, as well as continuous respect for others, in order to become a global success story.

\section{BIBLIOGRAPHY}

1. An-Na'im, Abdullahi Ahmed. Human Rights in Cross-Cultural Perspectives: A Quest for Consensus. $2^{\text {nd }}$ Edition. Philadelphia: University of Pennsylvania Press, 1995.

2. Arras, J., and E. Fenton. "Bioethics and human rights: access to healthrelated goods." Hastings Cent Rep 29 (2009): 27-38.

3. Atapattu, Sumudu. Human Rights Approaches to Climate Change: Challenges and Opportunities. New York: Routledge, 2015.

4. Ashcroft, Richard. "The troubled relationship between bioethics and human rights": 31-52. In: M. Freeman, ed. Law and Bioethics. Oxford: Oxford University Press, 2008.

5. Baker, Robert. "Bioethics and human rights: a historical perspective." Camb $Q$ Healthc Ethics 10 (2001): 241-252.

6. Beauchamp, Tom, and James Childress. Principles of Biomedical Ethics. $6^{\text {th }}$ Edition. Oxford: Oxford University Press, 2009.

7. Benedict, Ruth. Patterns of Culture. Boston: Houghton Mifflin Company, 1934. 
8. Boylan, Michael. Natural Human Rights: A Theory. Cambridge: Cambridge University Press, 2014.

9. Buchanan, Allen. Justice, Legitimacy, and Self-Determination: Moral Foundations for International Law. Oxford: Oxford University Press, 2004.

10. Buitenweg, Rob. Human Rights, Human Plights in a Global Village. Atlanta: Clarity Press, 2007.

11. Caney, Simon, and Peter Jones. Human Rights and Global Diversity. London, Portland: Frank Cass Publishers, 2001.

12. Caney, Simon. "Human Rights, Compatibility and Diverse Cultures." Critical Review of International Social and Political Philosophy 3.1 (2000): 51-76.

13. Carson, T., and P. Moser. Moral Relativism. A Reader. Oxford: Oxford University Press, 2001.

14. Cranston, Maurice. What Are Human Rights? London: Bodley Head, 1973.

15. Cranston, Maurice. "Human Rights, Real and Supposed": 163-173. In: D. Raphael, ed. Political Theory and the Rights of Man. London: Indiana University Press, 1967.

16. Crawford, James. The Rights of Peoples. $2^{\text {nd }}$ Edition. Oxford: Clarendon Press, 1992.

17. Donaldson, Sue, and Will Kymlicka. Zoopolis. A Political Theory of Animal Rights. Oxford: Oxford University Press, 2013.

18. Donelly, Jack. Universal Human Rights in Theory and Practice. $2^{\text {nd }}$ Edition Ithaca. New York: Cornell University Press, 2003.

19. Gewirth, Alan. Human Rights: Essays on Justification and Application. Chicago: University of Chicago Press, 1982.

20. Gordon, John-Stewart. "Human Rights". In: Duncan Pritchard, ed. Oxford Bibliographies in Philosophy. Published online, 2015.

21. Gordon, John-Stewart. "Human rights in bioethics: theoretical and applied." Ethical Theory and Moral Practice 15/3 (2012): 283-294.

22. Gordon, John-Stewart. "Global ethics and principlism." Kennedy Institute of Ethics Journal 21/3 (2011): 251-276.

23. Gordon, John-Stewart, Oliver Rauprich, and Jochen Vollmann. "Applying the Four-Principle Approach." Bioethics 25/6 (2011): 293-300.

24. Gordon, John-Stewart. "Poverty, human rights and just distribution": 131142. In: M. Boylan, ed. International Public Health Policy and Ethics. Berlin: Springer, 2008.

25. Griffin, James. On Human Rights. Oxford: Oxford University Press, 2009.

26. Huntington, Samuel P. The Clash of Civilizations and the Remaking of World Order. New York: Touchstone, 1996. 
27. Knowles, L. "The lingua franca of human rights and the rise of global bioethics." Camb Q Healthc Ethics 10(3) (2001): 253-263.

28. Kopelman, Loretta. "Female circumcision/genital mutilation and ethical relativism": 307-325. In: Paul K. Moser and Thomas L. Carson, eds. Moral Relativism: A Reader. Oxford: Oxford University Press, 2001.

29. Korsgaard, Christine. The Sources of Normativity. Cambridge: Cambridge University Press, 1996.

30. Locke, John. Two Treatises of Government. Edited by Peter Laslett. Cambridge: Cambridge University Press, 1960.

31. Mackie, John L. Ethics. Inventing Right and Wrong. London: Harmondsworth, 1977.

32. Macklin, Ruth. Against Relativism. Cultural Diversity and the Search for Ethical Universals in Medicine. New York, Oxford: Oxford University Press, 1999.

33. Meyer, Thomas. Identitätspolitik. Vom Missbrauch des kulturellen Unterschieds. Frankfurt am Main: Suhrkamp, 2002.

34. Nickel, James. Making Sense of Human Rights. $2^{\text {nd }}$ Edition. Oxford: WileyBlackwell, 2007.

35. Orend, Brian. Human Rights: Concept and Context. Peterborough: Broadview Press, 2002.

36. Paul, Ellen F., Fred D. Miller, and Jeffrey Paul. Economic Rights. Cambridge: Cambridge University Press, 1992.

37. Perry, Michael. The Idea of Human Rights: Four Inquiries. $2^{\text {nd }}$ Edition. Oxford: Oxford University Press, 2000.

38. Pollis, Adamantia, and Peter Schwab. "Human Rights: A Western Concept with Limited Applicability": 1-18. In: Adamantia Pollis and Peter Schwab, eds. Human Rights: Cultural and Ideological Perspectives. New York: Praeger, 1979.

39. Rachels, James. "The challenge of cultural relativism": 53-65. In: Paul K. Moser and Thomas L. Carson, eds. Moral Relativism: A Reader. Oxford: Oxford University Press, 2001.

40. Ram-Tiktin, Efrat. "The right to health care as a right to basic human functional capabilities": 1-15. In: John-Stewart Gordon, ed. Special Issue: Human Rights in Bioethics. Springer, published online 2012.

41. Rawls, John. The Law of Peoples. Cambridge: Harvard University Press, 1999.

42. Raz, Joseph. The Morality of Freedom. Oxford: Oxford University Press, 1986.

43. Renteln, Alison Dundes. The Cultural Defense. Oxford, New York: Oxford University Press, 2004. 
44. Rorty, Richard. "Human Rights, Rationality and Sentimentality": 111-134. In: Stephen Shute and Susan Hurley, eds. On Human Rights: The Oxford Amnesty Lectures 1993. New York: Basic Books, 1993.

45. Sen, Amartya. Identity and Violence. The Illusion of Destiny. New York, London: W. W. Norton \& Company, 2007.

46. Talbott, William. What Rights Should Be Universal? Oxford: Oxford University Press, 2005.

47. Vlastos, Gregory. "Justice and Equality": 41-76. In: Jeremy Waldron, ed. Theories of Rights. Oxford: Oxford University Press, 1984. 